\title{
Effort to Reduce Fat and Cholesterol of Quail Eggs Using Citronella Oil in Feed
}

\author{
Elly Tugiyanti ${ }^{1, *}$, and Soegeng Herijanto ${ }^{2}$ \\ ${ }^{I}$ Departemen of Animal Production, Faculty of Animal Science, University of Jenderal Soedirman \\ ${ }^{2}$ Departemen of Animal Production, Faculty of Animal Science, University of Wijaya Kusuma \\ *Corresponding author. Email: elly.tugiyanti@unsoed.ac.id
}

\begin{abstract}
The purpose of this study was to determine the effect of citronella oil supplementation in feed on fat and cholesterol levels of quail eggs (Coturnix coturnix japonica). The materials used were 100 female quail Coturnix-coturnix japonica, quail commercial feed, commercial citronella oil. The design used was Completely Randomized Design (CRD) with four treatments and five replications. The treatments included citronella oil supplementation $0.3 \%, 0.6 \%, 0.9 \%$ per $\mathrm{kg}$ feed. The experimental research was carried out for 8 weeks. The data obtained were analyzed for variance (ANOVA) and Duncan's Multiple Range Test (DMRT). Analysis of variance showed that the treatment of citronella oil supplementation in the feed had no effect $(\mathrm{P}>0.05)$ on egg protein but significantly $(\mathrm{P}<0.05)$ on cholesterol and had a very significant effect $(\mathrm{P}<0.01)$ on egg fat content.- In conclusion, giving citronella oil as much as $0.6 \%$ per $\mathrm{kg}$ of feed can reduce fat and cholesterol in quail eggs.
\end{abstract}

Keywords: Egg quality, Female quail, Egg fat, Egg cholesterol .

\section{INTRODUCTION}

The current problem is that the productivity of quail eggs is not optimal, one of the causes is low feed efficiency [1]. This adversely affects the quail growth and results in low body weight gain. On the other hand Quail eggs are considered as healthy nutritious food. The growth and production of quail can be optimally if the metabolic process is good. Metabolic results are supported by the amount of feed consumed and the optimization of feed use.

The food consumed has better digestibility with the presence of essential oils in the feed, so that the nutrients in the feed are easily absorbed. Lemongrass essential oil contains antiseptic and antibacterial properties so that it can kill pathogenic bacteria in the digestive tract $[2,3]$. [4] explained that the content of citronellal, geraniol, and citronellol in Citronella oil can inhibit bacterial activity.

State that Citronella oil shows great potential as an antibacterial agent that can suppress the activity of bacteria[5,6]. Putriningtyas[7]) in her study reported that citronella leaf essential oil from Tawangmangu was able to produce an inhibitory zone against $\mathrm{S}$. aureus and $\mathrm{E}$. coli. That essential oils can reduce the population of pathogenic bacteria that can damage the villi, and increase the population of lactic acid bacteria which can increase the density of the villi, so that the number of villi increases, and nutrients can be absorbed completely [8].

Reported that supplements an herbal essential oil mixture on the diet can overcome coccidiosis broiler chickens[9]. The study results by [10] so that the essential oil found in lemongrass can increase body weight gain and function as an anti-bacterial, especially in the digestive tract, thereby increasing growth livestock.

Citronella oil extract is able to increase broiler body weight gain [11]. The highest weight gain was achieved in broilers who consumed rations with Citronella oil extract $0.5 \%$, which was $1.160 \mathrm{~g}$ and tended to decrease in Citronella oil extract treatment, and the smallest body weight was obtained in broiler chickens that were given control rations which only reached $986 \mathrm{~g}$. These results are contradictory with the finding of [12] that broilers fed diets treated with various levels of lemongrass oil (LGO) consumed significantly more amount of feed compared to the broilers fed control, but which was statistically non significant. 
Supplementation of lemongrass leaf meal powder at the various levels in the broiler chick's diet substantially decreased serum cholesterol, triglyceride and increased the glucose, total protein level and improved the LDL/HDL ratio[13].

The results of these studies already knew that Citronella oil is able to inhibit the growth of bacteria, thus the livestock will easily digest their food and thus the growth and consumption of feed in livestock will increase periodically. Undoubtedly, based on the ability of Citronella oil as an antimicrobial and able to increase growth in poultry, it is necessary to have study the influence of Citronella to reduce egg cholesterol and egg fat of quail.

\section{MATERIALS AND METHODS}

\subsection{Quails}

As much as one hundred female quails (Cortunix cortunix japonica) (age 2 weeks) were used in the study. Quails were fed with four treatments in completely randomized design (CRD). Quail was housed in wire cages with dimensions of $35 \times 25 \times 25 \mathrm{~cm}$ (width, length, height). The experiment diets and water were given ad libitum for all groups. Quails were randomized to four diet treatments. Each treatment had five replicated of five female quails (Coturnix coturnix japonica).

\subsection{Research Design}

In four treatments, one was given $0 \%$ Citronella oil per $\mathrm{kg}$ of feed (T1) as the control diet, and the other diets were suplemented with the level of Citronella oil, namely, $0.3 \%$ Citronella oil per $\mathrm{kg}$ of feed (T2) per $\mathrm{kg}$ of feed, $0.6 \%$ Citronella oil per kg of feed (T3), and $0.9 \%$ Citronella oil per $\mathrm{kg}$ of feed (T4). The parameter measured were egg protein, cholesterol and egg fat content. The data obtained were analyzed for variance (ANOVA) and Duncan's Multiple Range Test (DMRT).

\subsection{Collection of Egg}

When the quails have been producing for four weeks, the eggs were then collected and analyzed for protein, fat and cholesterol content. Each cage unit was taken 5 eggs, so the number of eggs observed was 100 eggs. The method used to analyze egg cholesterol was the Liebermann Burchard method [14], while the method for protein analysis uses the Kjedhal method (Rosaini et al., 2015) and the method for fat analysis uses the Soxhlet method [15].

\subsection{Diet Experiment}

The study used commercially diet available in packs produced by New Hope Indonesia. The ingredient composition and nutrient content of the diets for experimental are presented in Table 1. The citronella oil extract used is available in the market in packaging produced by Agroatsiri.

Table 1. Nutrient content of the diets

$$
\text { Nutriens }
$$

Percentages (\%)

\begin{tabular}{|l|c|}
\hline Water content (max) & 13.0 \\
\hline Protein & $22-24$ \\
\hline Fat (min) & 5.0 \\
\hline Crude Fiber (max) & 5.0 \\
\hline Ash (max) & 7.0 \\
\hline Calcium (min) & 0.9 \\
\hline Phosphor (min) & 0.6 \\
\hline Metabolic energy (kkal/kg) & 2900 \\
\hline
\end{tabular}

References: PT. New Hope Indonesia

\section{RESULTS AND DISCUSSION}

The average mean of egg protein, egg cholesterol and egg fat content of female quail (Cortunix cortunix japonica) as influenced of dietary inclusion of citronella oil are presented in Table 2.

The statistical analysis on egg protein parameters had no significant difference $(\mathrm{P}>0.05)$ among the dietary treatment. Shown in Table 2 that the average the-levels of egg protein in $\mathrm{T} 1$ as control $(11.22 \pm 0.93 \mathrm{mg} / \mathrm{dl})$ was lowest as compared to the other treatments i.e. T2 $(12.37 \pm 1.11 \mathrm{mg} / \mathrm{dl}), \mathrm{T} 3(11.34 \pm 1.17 \mathrm{mg} / \mathrm{dl})$ and $\mathrm{T} 4$ $(11.71 \pm 1.07 \mathrm{mg} / \mathrm{dl})$, respectively. It is indicated that the optimum beneficial effect of citronella oil supplementation as an herbal feed additive up to $0.9 \%$ per $\mathrm{kg}$ of feed of can be increasing the level of egg protein.

The trend of average the levels of egg cholesterol of quail is given in Table 2. The egg cholesterol was lowest in $\mathrm{T} 3(362.19 \pm 11.19 \mathrm{mg} / \mathrm{dl})$, followed by $\mathrm{T} 4$ $(363.68 \pm 5.21 \mathrm{mg} / \mathrm{dl}), \mathrm{T} 2(378.53 \pm 14.89 \mathrm{mg} / \mathrm{dl})$ and highest value in $\mathrm{T} 1$ as control group $(382.15 \pm 9.87$ $\mathrm{mg} / \mathrm{dl})$.

Analysis of variance showed that the treatment of citronella oil supplementation in the feed had significantly effect $(\mathrm{P}<0.05)$ on egg cholesterol. Duncan's Multiple Range Test (DMRT) indicated that T3 and T4 significantly different $(\mathrm{P}<0.05)$ to $\mathrm{T} 1$, it is showed that the beneficial effect of citronella oil supplementation as an herbal feed additive as much $0.6 \%$ Citronella oil per $\mathrm{kg}$ of feed of can be reduce the level of egg cholesterol.

Similar observations by [16] who report that combination of probiotics with ginger were inoculated in laying quail diet can decrease total cholesterol levels in serum and yolk (107.05 mg/dl and $10.6 \mathrm{mg} / \mathrm{g})$ respectively compared to control group $(158 \mathrm{mg} / \mathrm{dl}$ and $14.1 \mathrm{mg} / \mathrm{dl}$ ). Parade et al. (2019) that the cholesterol and high density lipoprotein (HDL) serum of the broiler 
chickens was quantitatively lowest in experimental chickens receiving lemongrass leaf meal 1.5 per cent level as compared to control group without lemongrass leaf meal. Besides that low density lipoprotein (LDL) serum of the broiler was quantitatively highest in chickens receiving lemongrass leaf meal 1.5 per cent level as compared to control group without lemongrass leaf meal. The other study by [17] also reported that quail egg cholesterol decreased significantly in the $400 \mathrm{ppm}$ niacin treatment, and continued to decrease the greater

$0.5 \%$ and $1 \%$ supplemented with ginger root powder $(66.33 \mathrm{mg} / \mathrm{dl}$ and $58.33 \mathrm{mg} / \mathrm{dl})$ compared to control group (94.33 mg/dl).

That study is contradictory with the finding of [18]who reported that the use of turmeric powder with a level of $54 \mathrm{mg} / \mathrm{bird} /$ day does not affect feed consumption and egg cholesterol levels quail produced at the age of 4 months, but the use of turmeric powder with a level of 54 $\mathrm{mg} / \mathrm{bird} /$ day when became sexual maturity has an impact on increasing levels of quail egg cholesterol. As well the study by [19] report that serum cholesterol levels were not affected by the fenugreek seed powder as phytogenic feed additives in broiler diet.

Another study found that Cymbopogon citratus leaf meal has impact on poultry body weight. [13]that Cymbopogon citratus leaf meal in poultry diets resulted in significantly $(\mathrm{P}<0.05)$ higher body weight compared to

Table 2. The egg protein, cholesterol and egg fat content of quaile (Cortunix cortunix japonica)

\begin{tabular}{|c|c|l|l|}
\hline Treatment & Egg protein $(\mathrm{mg} / \mathrm{dl}) \mathrm{ns}$ & Egg Cholesterol $(\mathrm{mg} / \mathrm{dl})$ & Egg fat $(\mathrm{mg} / \mathrm{dl})$ \\
\hline T1 & $11.22 \pm 0.93$ & $382.15 \pm 9.87^{\mathrm{a}}$ & $23.95 \pm 0.41^{\mathrm{c}}$ \\
\hline T2 & $12.37 \pm 1.11$ & $378.53 \pm 14.89$ & $19.53 \pm 0.42^{\mathrm{d}}$ \\
\hline T3 & $11.34 \pm 1.17$ & $362.19 \pm 11.19^{\mathrm{b}}$ & $17.42 \pm 0.81^{\mathrm{e}}$ \\
\hline T4 & $11.71 \pm 1.07$ & $363.68 \pm 5.21^{\mathrm{b}}$ & $17.40 \pm 0.44^{\mathrm{e}}$ \\
\hline
\end{tabular}

${ }^{\mathrm{ns}}$ non significant; ${ }^{\mathrm{ab}}$ significant different $(\mathrm{P}<0.05) ;{ }^{(\mathrm{cd})(\mathrm{ce})(\mathrm{de})}$ very significant different $(\mathrm{P}<0.01)$ control diet at the end of 6 th week. In contradictory to the finding of [20] who report that the quail (unsex) diet supplemented with $3 \%$ Lemmon grass leaf meal showed a significantly lower final body weight compared to the control $(p<0.05)$. This was similar with [21] who reported that reduced body weight in broilers fed with $2 \%$ Lemmon grass leaf supplemented. The other study by [22] report that the lemongrass oil did not affect significantly on body weight gain during experiment period from initial to end of the experiment (36 days).

Our experiment showed that egg fat of quail treated with various levels of citronella oil quantitatively more 2. The egg fat was lowest in T4 $(17.40 \pm 0.44 \mathrm{mg} / \mathrm{dl})$, folowed by T3 $(17.42 \pm 0.81 \mathrm{mg} / \mathrm{dl}), \mathrm{T} 2(19.53 \pm 0.42$ $\mathrm{mg} / \mathrm{dl}$ ) and highest value in $\mathrm{T} 1$ as control group $(23.95 \pm 0.41 \mathrm{mg} / \mathrm{dl})$. lower compared to the control group as showed in Table the niacin level. The further explaination is that the addition of niacin in the feed significantly reduce HDL and increase LDL. The function of LDL is to send cholesterol to the coronary vessel tissue which can cause calcium accumulation in the coronary blood vessels, while function HDL is absorbing cholesterol deposits in the tissue and then send it to the liver and then break down into bile acids. The study by [23] that serum cholesterol of unsexed broiler were significantly lower $(\mathrm{P}<0.05)$ in

Analysis of variance showed that the treatment of citronella oil supplementation in the feed had very significantly effect $(\mathrm{P}<0.01)$ on egg fat. Duncan's Multiple Range Test (DMRT) indicated that T1 very significantly different $(\mathrm{P}<0.01)$ to $\mathrm{T} 2, \mathrm{~T} 3$ and $\mathrm{T} 4$. Other wise $\mathrm{T} 2$ significantly different $(\mathrm{P}<0.01)$ to $\mathrm{T} 3$ and $\mathrm{T} 4$, but $\mathrm{T} 3$ had non different to T4. So this trend showed that the beneficial effect of citronella oil supplementation as an herbal feed additive as much $0.3 \%$ per $\mathrm{kg}$ of feed of can be reduce the level of egg fat.

These findings were in agreed with those of [16]found that the use of niacin as much as $1000 \mathrm{ppm}$ in feed was able to reduce triglyceride serum levels from 155.52 become $100.19(\mathrm{mg} / \mathrm{dl})$ in female quails. These results contradictory with the finding by [12] who report that triglyceride serum of broiler with supplemented $1.5 \%$ level of lemongrass leaf meal $(147.50 \mathrm{mg} / \mathrm{dl})$ was significantly different $(\mathrm{P}<0.05)$ than other three groups i.e. supplemented $1.0 \%(140.25 \mathrm{mg} / \mathrm{dl})$, supplemented $0.5 \%(136.75 \mathrm{mg} / \mathrm{dl})$ and control group $(130.50 \mathrm{mg} / \mathrm{dl})$. Similar the study by Zomrawi et al. (2012) that serum triglyceride of unsexed broiler were significantly lower $(\mathrm{P}<0.05)$ for control group $(44 \mathrm{mg} / \mathrm{dl})$ and $0.5 \%$ supplemented with ginger root powder $(25.67 \mathrm{mg} / \mathrm{dl})$ compared to other treatments i.e. $1.5 \%$ supplemented $(99.33 \mathrm{mg} / \mathrm{dl})$ and $1.0 \%$ supplemented $(62.33 \mathrm{mg} / \mathrm{dl})$

\section{CONCLUSION}

From this research it can be concluded that giving citronella oil as much as $0.6 \%$ per $\mathrm{kg}$ of feed can reduce fat and cholesterol in quail eggs. 


\section{REFERENCES}

[1] Primacitra, Y.D., O. Sjofjan, dan M.H. Natsir.2014.Pengaruh Penambahan Probiotik(Lactobacillus Sp.) dalam Pakan terhadap Energi Metabolis, Kecernaan Protein dan Aktivitas Enzim Burung Puyuh. J. Ternak Tropika, vol. 15 , no. 1, pp. 74-79

[2] Behura, S., dan V.K. Srivastav. 2004. Essential oil of leave of curcuma species. Journal of Essential Oil Research. 16(2): 109-110

[3] Puspawati, N.M., I.W. Suirta, dan S. Bahri. 2016.Isolasi, Identifikasi, Serta Uji Aktifitas Antibakteri Pada Minyak Atsiri Sereh Wangi (Cymbopogon winterianus Jowitt). Jurnal Kimia. 10 (2) : 219-227.

[4] Luangnarumitchai S., Lamlertthon, S., and Tiyaboonchai, W. 2007. Antimicrobial activity of essential oils against five strains of Propionibacterium acnes. Mahidol University Journal of Pharmaceutical Sciences. 34: 60-64.

[5] Ibrahim, Hayam M., Ferial M. Abu Salem. (2013). Effect of Adding Lemongrass and Lime Peel Extracts on Chicken Patties Quality. Journal of Applied Sciences Research. 9(8). 5036.

[6] Paramartha D.A. 2015. Kajian Aktivitas Antibakteri Minyak Daun Sereh (Cymbopogon citratus) pada Adonan Sate Lilit Ikan Laut. Jurnal Media Ilmiah Teknologi Pangan (Scientific Journal of Food Technology). 2 (1). 029-040.

[7] Calsamiglia S., M. Busquet, P.W Cardozo, L. Catillejos, and A. Ferret. 2007. Invited Review: essential oils as modifiers of rumen microbial fermentation. J Dairy Sci. 90:2580- 2595

[8] Sjofjan, O., D.N. Adli, M.H. Natsir, dan A, Kusumaningtyaswati. 2020. Pengaruh Kombinasi Tepung Kunyit (Curcuma domestica VAL.) dan Probiotik Terhadap Penampilan Usus Ayam Pedaging. Jurnal Nutrisi Ternak Tropis dan Ilmu Pakan. 2(2) : 19-24.

[9] Bozkurt M., N. Aysul , K. Küçükyilmaz, S. Aypak , G. Ege , A. U. Çatli, H. Akşit, F. Çöven, K. Seyrek, and M. Çınar. 2014. Efficacy of in-feed preparations of an anticoccidial, multienzyme, prebiotic, probiotic, and herbal essential oil mixture in healthy and Eimeria spp.-infected broilers. Poultry Science 93 :389-399

[10] Lee K. W., Everts, H. and Beyne, A. C. 2004. Essentials oils in broiler nutrition. International Journal of Poultry Science. 3 (12): 738 - 752
[11] Rumokoy L., Charles Kaunang, and W. Toar. 2017. Efek ekstrak minyak citronela Cymbopogon nardus L. terhadap proporsi frekuensi kontak fisik Musca domesticaL. (Diptera: Muscidae) pada ransum dan performa broiler. Indonesian Journal of Entomology. 14 (2): 89-96.

[12] Tiwari M. R., Jha P. K., Sah B., Kunwar G. and Jha A. K. 2018. Performance of Lemongrass (Cymbopogon citrates) Oil as Growth Promoter in Broiler. Bang. J. Anim. Sci., 47(2): 85-91.

[13] Parade A. K., B. M. Thombre, R. A. Patil, P. V. Padghan, S. S. Shinde and P. B. Meshram. 2019. Inclusion of Lemongrass (Cymbopogon citratus) Leaf Meal as a Natural Feed Additive for Evaluation Serum Lipid Profile of Broilers. Int. J. Curr. Microbiol. App. Sci. 8(10): 1835-1841.

[14] Adu, J.K., Cedric D. K. A, Naomi K., Emmanuel O., Stella A.G.P., Bernice K.O. 2019. Validation of a Simple and Robust Liebermann-Burchard Colorimetric Method for the Assay of Cholesterol in Selected Milk Products in Ghana", Int.J. Food Science, 2019, Article ID 9045938, 7 pages. https://doi.org/ 10.1155/2019/9045938

[15] Aminullah, Mardiah, Muhammad Reza Riandi, Arum Puspito Argani, Gustini Syahbirin, and Tetty Kemala. 2018. The Effect of Types of Fat Extraction Methods on Total Lipids of Chicken and Pork Fat. Journal of Halal Agroindustry 4 (1): 094- 100

[16] Khalifa M I and Noseer E A. 2019 Cholesterol quality of edible eggs produced by quail fed diets containing probiotic and/or ginger (Zingiber officinale). Livestock Research for Rural Development. Volume 31, Article \#165. RetrievedAugust 1, 2021, from http://www.lrrd.org/lrrd31/10/mrwa31165.html

[17] Aviati,V., S.M. Mardiati and T.R. Saraswati, 2014. Kadar Kolesterol Telur Puyuh Setelah Pemberian Tepung Kunyit Dalam Pakan. Buletin Anatomi dan Fisiologi. 22(1): 58-64

[18] Fenita Y and T Suteky. 2006. Pengaruh Pemberian Niacin Terhadap Kadar Kolesterol Telur dan Perlemakan Serum Darah Puyuh (Cortunix cortunix japonica). Jurnal Sain Peternakan Indonesia. 1(2): 45-48.

[19] Weerasingha A. S. and N.S.B.M. Atapattu. 2013. Effect of Fenugreek (Trigonella foenumgraecum L.) Seed powder on Growth Performance, 
Visceral Organ Weight, Serum Cholesterol Levels and the Nitrogen Retention of Broiler Chicken. Tropical Agricultural Reserch. 24(3):289-295.

[20] Sariözkan S, Y Konca, GüçlüBk, E Aktuğ, M Kaliber, Ş Özkan and ST Ay (2016). The effect of dietary supplementation of lemongrass (Cymbopogoncitratus) on performance, carcass

[21] Thayalini, K., Shanmugavelu, S., Saminathan, P.M., Siti Masidayu, M.S., Nor Idayusni, Y., Zainuddin, H., Nurul Akmal, C.A. and Wong, H.K. 2016. Effects of Cymbopogon citratus leaf and Zingiber officinale rhizome supplementation on growth performance, ileal morphology and lactic acid concentration in broilers. Mal. J. Anim. Sci. 14:43-49

[22] Tiwari M. R., Jha P. K., Sah B., Kunwar G. and Jha A. K. 2018. Performance of Lemongrass (Cymbopogon citrates) Oil as Growth Promoter in Broiler. Bang. J. Anim. Sci., 47(2): 85-91.

[23] Zomrawi W. B., KH. A. Abdel Atti, B. M. Dousa and A. G. Mahala. 2012. The Effect of Ginger Root Powder (Zingiber Officinale)Supplementation on Broiler ChicksPerformance, Blood and Serum Constituents. Online Journal Anim. and Feed Reserch. Vol. 1(6): 457- 